Jasmina S. Petrović ${ }^{1}$

DRAGANA S. ZAHARIJEVSKI ${ }^{2}$

\title{
STUDENTS' PERCEPTION OF MARRIAGE, FAMILY AND PARENTHOOD IN THE LIGHT OF RELIGIOUS IDENTITY AND RELIGIOUS TOLERANCE: A COMPARATIVE PERSPECTIVE ${ }^{3}$
}

ABSTRACT. In a comparative perspective, the paper shows students' attitudes towards family, marriage and parenthood obtained in an empirical study entitled "Cultural orientation of actors/students, interethnic relations, national identity and the culture of peace in the Balkans" on the samples from the University of Bitola, Veliko Tarnovo and Niš. It analyzes findings from the three subsamples, and tests the hypothesis that students' religiousness and the firmness of their religious beliefs predicate their attitudes towards family, marriage and parenthood, irrespective of the country where they study. It is expected that the student youth in all subsamples shows preference for the individualistic model of partnership, symmetrical parenting, egalitarian partner and family relationships, but also that the choice of some attitudes

jasmina@medianis.net

draganazaharijevski@gmail.com

The paper presents the results of research conducted under the Project Sustainability of the Identity of Serbs and National Minorities in the Border Municipalities of Eastern and Southeastern Serbia (179013) and the project Tradition, Modernization and National Identity in Serbia and the Balkans in the EU Integration Process" (179074), conducted at the University of Niš - Faculty of Mechanical Engineering and Faculty of Philosophy, supported by the Ministry of Science and Technological Development of the Republic of Serbia.

This paper was submitted on 21 August 2015 and accepted for publication at the meeting of the Editorial Board held on 8 October 2015. 
clearly indicates the presence of traditional value patterns. At the same time, it is assumed that respondents who identify themselves as firm believers, and those who express a lower level of religious tolerance towards other religions, largely follow traditional patterns in the notion of marriage, family and parenthood.

KEY WORDS: marriage, family, parenthood, Bitola, Veliko Tarnovo, Niš, students

\section{ON APPLIED METHODOLOGY}

On the data obtained in the study Cultural orientation of actors/ students, interethnic relations, national identity and the culture of peace in the Balkans, performed on a subcluster sample of university students in Niš, Bitola and Veliko Tarnovo, the general assumption regarding the presence of traditional and modern attitudes in the notion of marriage, family, parenthood and gender relations is being tested. Also, it is assumed that there is a difference in the expressed attitudes in these areas among the students who are differently oriented according to religion: firm believers and those who expressed less tolerance for religious teachings often have traditional beliefs about marriage, family and gender relations. Hypotheses were checked by means of testing the statistical difference in responses in groups formed according to religious selfidentification and the established views on religious beliefs.

The survey was conducted in December, 2012, in Serbia and January, 2013, in Macedonia and Bulgaria. The sample of 2400 planned respondents was formed through three subsamples with the same number of respondents in regional and university centres. It is a sample of subcluster type, designed so that, at the level of subsamples for each of these university centres, the way of selecting units in each segment of sampling ensures the presence of students with certain socio-demographic characteristics of significance for the tested problem (professional and educational profile, year of study). The presence of groups of respondents with mentioned characteristics and other qualities of interest for research was provided by the procedure of random selection at every stage of sample creation on the one hand, and respecting the proportions relating to the portion of students in some faculty groups and their number in some faculties within groups (Petrović, 2014, p. 13). The research was conducted by means of the survey method, using a questionnaire which covered a range of topics, much wider than 
the one presented in this paper. The sample had 2,208 units. ${ }^{4}$ Claims used to examine the models of value patterns aiming at marriage, family life and gender relations present a relatively structured family relations. These are the forms of mutual relations among actors within the family structure examined through the attitudes on certain family roles, gender relations within the family, parental roles, and finally, the general attitude towards marriage. Tested views were interpreted as dimensions of family values, with the aim of establishing a preference of students to a particular type of family value matrix and their gender sensitivity as a kind of an indicator of preference of traditional or modern models of marriage and family organization. Bearing in mind previous similar studies, a series of representative claims were selected in order to establish a tendency towards a certain type of family relations, whereby it is assumed that it is possible to identify, so to speak, two ideal-typical models: the traditional one patriarchal family values and archaic gender stereotypes in its base and the modern one - marked by liberal values and commitment to gender equality (Ivanov, 2008; Zaharijevski, Petrović, 2009; Zaharijevski, Gavrilović, 2010).

Students' religious beliefs were examined on a six-degree attitude scale of religious self-declaration, tested in a number of previous studies on religiosity. This scale "measures" the degree of religiosity: from complete certainty in a specific faith, through moderate belief and religious volatility, indifference to religion and expression of irreligiousness with (in)opposition to religion. ${ }^{5}$ The scale of religious tolerance which establishes a qualitative attitude towards different religious teachings was also applied. It included options of confidence in the truth of one "true religion", through appreciation of the existence of other religious options despite dominating confidence in one religion and the attitude that reflects religious tolerance towards religious teachings of the world religions to the agnostic attitude when it comes to religious teachings ${ }^{6}$.

4 For more information on the selection of units from the general population see the text on the sample, the instrument and the realization of the research, J. Petrović (2014, p. 11-16).

5 The choices offered on this scale are: a) I am a firm believer and accept everything that my religion teaches; $b$ ) I am religious, but I do not accept everything that my religion teaches; c) I'm thinking about it, but I am not sure if I am a believer or not; d) I am indifferent to religion; e) I'm not religious, but I have nothing against religion; f) I am not religious and I am against religion; 


\section{THE PERCEPTION OF MARRIAGE AS AN INSTITUTION, RELIGIOUS SELF-IDENTIFICATION AND RELIGIOUS TOLERANCE}

A theoretical basis for the analyses that follow can be found in Inglehart's (Roland Inglehart) "revised theory of modernization" which discusses the relationship between socio-economic and value spheres of society and concludes that the development of the socioeconomic sphere does not guarantee the evolution of values, and so the "industrialization can lead to fascism, communism, theocracy or democracy" (Inglehart, Welzel, 2010, pp. 551-567), precisely because of the reversibility of the process of modernization and the persistence of traditional values. After analysing the test values (WBC and EVS) Inglehart operationalizes some of the attitudes towards religion and the family (whose presence implies the existence of traditional values) as focal values, offering a scale of attitudes representing traditional values (we highlight: "Religion is very important in respondent's life", "Respondent attends church regularly", "Respondent describes self as 'a religious person", "Family is very important in respondent's life", "Respondent favours having a relatively large number of children", "If a woman earns more money than her husband, it's almost certain to cause problems", etc.) (Inglehart, 2000, p. 22). Research in 65 societies, with the application of this scale, shows that there is the process of transition from traditional values to secular-rational in the postsocialist countries.

Although marriage in the Balkans is the backbone of making a family, students at all three universities are not so unanimous when it comes to the evaluation of marriage as an institution. Every fifth student at the University of Veliko Tarnovo agrees with the statements referring to marriage is an obsolete institution, while the percentage of those who think the opposite is $73.3 \%$. Similar test results are obtained on the student population of the University of Bitola, where $73.8 \%$ disagreed with the statement that the

6 Options on the scale of religious tolerance were: a) There is only one true religion and the truth that it offers; b) There is only one true religion, but other religions do contain some basic truths; c) There is no one true religion, but all the world's religions contain some basic truths; d) None of the great religions offer any truths. 
institution of marriage is a part of the past, while $10.8 \%$ believe that marriage is an outdated form of joint life of men and women. Most respect towards marriage was expressed by the students of the University of Niš, who, according to the obtained findings, in $83 \%$ of cases do not express agreement with the statement that marriage is an obsolete institution. This sub-sample has the smallest share of the opponents of marriage - 8.1\% (Chart 2).

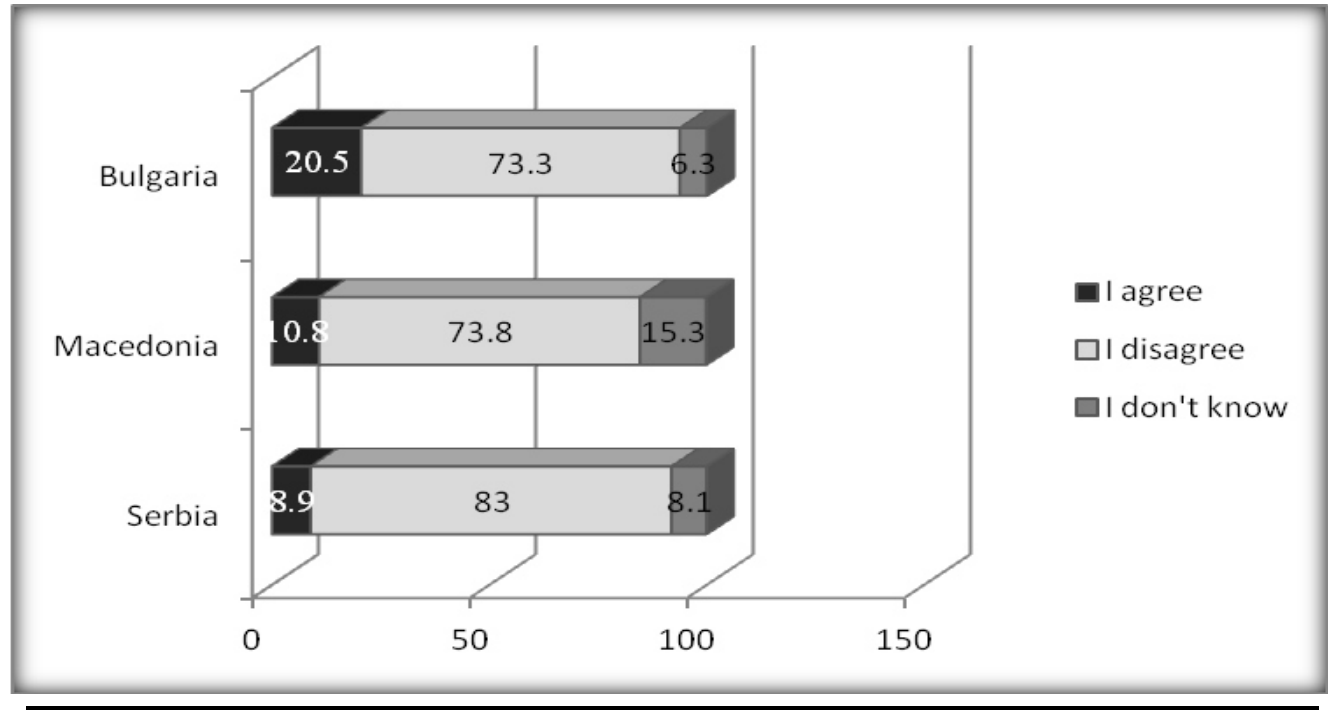

CHART 1. STUDENTS' ATTITUDE TOWARDS THE STATEMENT THAT MARRIAGE IS AN OBSOLETE INSTITUTION (FINDINGS FOR ALL SUB-SAMPLES EXPRESSED IN \%)

Testing the statistical significance of differences in students' attitudes towards the institution of marriage observed with regards to their religious self-identification shows that, at the level of the sample as a whole, it can be argued that there are significant differences in the attitudes of students towards marriage observed together with the level of religiosity $\left(\chi^{2}(10)=91.619\right.$ [N=2160] Sig. 0,000; Cramer's V= 0,146). Specifically, most of those who disagree with the statement that marriage is an obsolete institution (83.5\%) are among the firm believers who accept everything their religion teaches, while the percentage decreases in the groups expressing reservations about the religious teachings, of their own faith or of religious teachings in general. The lowest level of agreement with the aforementioned statement is expressed by the students who are not religious and who characterized themselves as opponents of religion $49.2 \%$. 
A similar result was obtained while testing statistical differences in attitudes toward marriage as an institution and the attitudes that 'recorded' the attitude towards the truths offered by religions or religious tolerance $(\mathrm{c} 2(8)=66.938$ [N=2179] Sig. 0,000; Cramer's $\mathrm{V}=0,124)$. Students who exhibit the lowest level of religious tolerance, saying that "there is only one true religion and the truth that it offers" more frequently disagree with the statement that marriage is an obsolete institution $80.2 \%$ than those with more tolerance relating to different religious teachings. The least agreement was observed in the group of subjects who exhibit an agnostic attitude towards all religious teachings ("None of the great religions offer any truths"), among which $67.1 \%$ disagreed with the statement that marriage is an obsolete institution.

By testing the statistical significance of differences in the students' attitudes towards marriage, observed through religious self-identification and religious tolerance at the level of all subsamples, it was found that there is a statistical significance in subsamples when it comes to students' attitude towards the institution of marriage and their religious self-declaration ${ }^{7}$ and the manifested tolerance towards religious teachings of other religions ${ }^{8}$.

\section{STUDENTS' ATTITUDES TOWARDS THE ASSUMPTIONS OF SUCCESSFUL MARRIAGE, FAMILY AND PARENTHOOD}

Students at all three universities maintained that mutual understanding, loyalty and love are of special importance for a successful marriage. Ordering the importance of these prerequisites for a successful marriage is not the same among students from different subsamples. Serbian students prioritize understanding, Macedoni-

7 Recorded parameters in religious self-identification: subsample Serbia (c2(8)= 47.215 [N=792] Sig. 0,000; Cramer's V= 0,173); subsample Macedonia does not havea statistical significance; subsample Bulgaria $(\mathrm{c} 2(8)=33.902[\mathrm{~N}=568]$ Sig. 0,000 ; Cramer's V= 0,173).

8 In religious tolerance: subsample Serbia $(c 2(8)=41.023[N=813]$ Sig. 0,000; Cramer's V= 0,159); subsample Macedonia $(c 2(8)=22.202$ [N=567] Sig. 0,003; Cramer's V=0,143); subsample Bulgaria $(\mathrm{c} 2(8)=22.202$ [N=567] Sig. 0,003; Cramer's V=0,143). 
an fidelity, and Bulgarian students love. For the respondents from each subsample, the fourth priority of the listed prerequisites of a successful marriage is the offspring (Table 1).

What can be concluded from the comparative analysis is that it shows a high similarity in the perception of other offered prerequisites of a successful marriage in the responses of Serbian and Bulgarian students, while the students of the University in Bitola have a somewhat different attitude regarding the importance of certain factors for establishing a harmonious marriage. Thus, they attach a considerable importance (option very important) to adequate income, sharing religious beliefs with a partner, as well as the same social background. Also, Macedonian students in more cases than the students from Serbia and Bulgaria place greater importance to sharing similar political beliefs with a partner. Students from the University of Veliko Tarnovo, give some more weight to becoming independent from their families of origin and good sexual relations as conditions for a successful marriage than the students from other universities do. Serbian students more often than their colleagues from other universities point out that the most important prerequisite for a successful marriage is enough time to devote to personal development, hobbies, friends, etc. (Table 1).

\begin{tabular}{c|ccccccccc}
\hline $\begin{array}{c}\text { PREREQUISITES FOR } \\
\text { A SUCCESSFUL } \\
\text { MARRIAGE }\end{array}$ & \multicolumn{3}{|c}{ VERY IMPORTANT } & \multicolumn{3}{c}{ IMPORTANT } & \multicolumn{3}{c}{ UNIMPORTANT* } \\
\cline { 2 - 10 } & Srb & Mk & Bug & Srb & Mk & Bug & Srb & Mk & Bug \\
\hline FIDELITY & 83.4 & 78 & 80,8 & 13.7 & 11,3 & 15,5 & 1.1 & 3,2 & 1,2 \\
ADEQUATE INCOME & 26.7 & 40,9 & 28,3 & 55.8 & 41,9 & 53,6 & 14.2 & 10,6 & 15,8 \\
$\begin{array}{c}\text { THE SAME SOCIAL } \\
\text { BACKGROUND }\end{array}$ & 6.9 & 22,4 & 11,5 & 22.5 & 22,3 & 26,0 & 62.5 & 44,4 & 54,4 \\
$\begin{array}{c}\text { SHARING THE SAME } \\
\text { RELIGIOUS BELIEFS }\end{array}$ & 15.7 & 33,2 & 16,4 & 26.3 & 27,9 & 25,3 & 48.6 & 26,7 & 50,0 \\
$\begin{array}{c}\text { GOOD HOUSING } \\
\text { CONDITIONS }\end{array}$ & 24.0 & 31,0 & 28,9 & 56.7 & 38,6 & 56,3 & 15.1 & 20,5 & 12,3 \\
$\begin{array}{c}\text { SIMILAR POLITICAL } \\
\text { BELIEFS }\end{array}$ & 6.1 & 16,3 & 6,7 & 15.3 & 18,2 & 16,0 & 68.6 & 51,4 & 69,1 \\
\hline \hline
\end{tabular}

TABLE 1: OVERVIEW OF STUDENTS' ATTITUDES TOWARDS CERTAIN FACTORS OF A SUCCESSFUL MARRIAGE (FINDINGS FOR ALL SUBSAMPLES EXPRESSED IN \%) 
Collection of Papers of the Faculty of Philosophy XLV (3)/2015

\begin{tabular}{|c|c|c|c|c|c|c|c|c|c|}
\hline $\begin{array}{l}\text { LIFE SEPARATED } \\
\text { FROM PARENTS }\end{array}$ & 37.3 & 32,3 & 52,6 & 31.9 & 27,7 & 31,9 & 23.1 & 25,9 & 10,8 \\
\hline $\begin{array}{l}\text { GOOD SEXUAL } \\
\text { RELATIONS }\end{array}$ & 56.0 & 54,3 & 64,9 & 35.7 & 26,4 & 30,2 & 4.4 & 8,3 & 2,6 \\
\hline $\begin{array}{c}\text { EQUAL } \\
\text { PARTICIPATION OF } \\
\text { SPOUSES IN } \\
\text { HOUSEWORK }\end{array}$ & 39.4 & 43,5 & 48,8 & 44.4 & 35,4 & 40,5 & 12.4 & 11,3 & 8,1 \\
\hline CHILDREN & 72.0 & 71,3 & 61,2 & 21.4 & 15,9 & 27,2 & 3.6 & 5,3 & 6,0 \\
\hline $\begin{array}{c}\text { MUTUAL } \\
\text { UNDERSTANDING }\end{array}$ & 86.2 & 73,6 & 70,4 & 11.6 & 73,6 & 23,3 & 0.6 & 5,5 & 2,5 \\
\hline $\begin{array}{l}\text { HAVING TIME FOR } \\
\text { FRIENDS AND } \\
\text { PERSONAL } \\
\text { ACTIVITIES AND } \\
\text { HOBBIES }\end{array}$ & 51.5 & 46,1 & 48,8 & 42.8 & 46,1 & 46,1 & 3.6 & 7,6 & 3,5 \\
\hline LOVE & 83.8 & 75,1 & 87,1 & 13.4 & 75,1 & 10,2 & 1.3 & 4,4 & 1,4 \\
\hline
\end{tabular}

TABLE 1: OVERVIEW OF STUDENTS' ATTITUDES TOWARDS CERTAIN FACTORS OF A SUCCESSFUL MARRIAGE (FINDINGS FOR ALL SUBSAMPLES EXPRESSED IN \%)

* The Table does not include the answers 'I don't know."

As one of the presumptions was that students' religious identification as well as demonstrated religious tolerance appear as predicates of attitudes toward marriage, the significance of these relations was tested. The values of the statistics show that at the level of the entire sample, we can say that there is a statistically significant difference in attitudes (regarding most offered attitudes) in groups of students with different religious declarations.

As expected, students' religiosity (determined through religious self-identification) is the predicate of the attitude about the importance of sharing religious beliefs for a successful marriage $(\mathrm{c} 2(15)=179.410$ [N=2157] Sig. 0,000; Cramer's V=0,167). However, religiosity appears as a determinant of attitudes about the importance of fidelity $(\mathrm{c} 2(15)=55.589$ [N=2161] Sig. 0,000; Cramer's $\mathrm{V}=0,93)$, children $(\mathrm{c} 2(15)=96.830[\mathrm{~N}=2158]$ Sig. 0,000; Cramer's $\mathrm{V}=0,122)$, understanding $(\mathrm{c} 2(15)=59.675[\mathrm{~N}=2159]$ Sig. 0,000; Cramer's V=0,96) and love (c2(15) $=42.914$ [N=2160] Sig. 0,000; Cramer's $\mathrm{V}=0,81$ ) for a successful marriage. The observed pattern is a 
constant that occurs in subsamples individually. Also, it has been shown that the answers of firm believers and those who are more volatile in terms of religion or non-religious differ in terms of the importance of specific factors relating to material and other social preconditions for marital harmony, such as adequate income $(\mathrm{c} 2(15)=54.748[\mathrm{~N}=2162]$ Sig. 0,000; Cramer's $\mathrm{V}=0,92)$, identical social status of spouses $(\mathrm{c} 2(15)=64.765[\mathrm{~N}=2158]$ Sig. 0,000 ; Cramer's $V=0,100)$ or similar political beliefs $(\mathrm{c} 2(15)=52.553[\mathrm{~N}=2160]$ Sig. 0,000; Cramer's $V=0,90$ ). Although some minor differences were established, they are significant when it comes to the attitude towards the importance of good sexual relations for a successful marriage or good housing conditions. The differences in the attitudes of students towards the importance of separation from the parents, enough time for personal activities and hobbies and equal participation of spouses in housework are not such that one could speak of statistically significant differences determined by religiosity.

These regularities are not mapped to the end in each subsample since in each of them different attitudes (than those listed in the instrument) appear to be determined by the students' religiosity. Religiosity primarily appears as a predicate of attitudes toward fidelity, offspring and love, however, when it comes to other prerequisites of a successful marriage, differences in the subsamples were detected. ${ }^{9}$

Students' attitudes toward marriage are determined not only by their self-declared religiosity, but also by the nature of religious

9 For example, the data for the subsample of students from the University of Niš point that "students' religiosity is the predicate of attitudes on the importance of the same religious beliefs, but also the importance of fidelity and the offspring for a successful marriage. Differences in attitudes towards the importance of an adequate income, identical social background, similar political beliefs, good housing conditions, and sufficient time for personal activities and hobbies, love and mutual understanding are not such that one could speak of statistically significant differences determined by religiosity" (Stjepanović, Zaharijevski, Petrović, 2014, p. 225). In the subsample Macedonia, there are statistically significant differences in the responses of students with different degrees of religiosity when it comes to the following conditions for a successful marriage: fidelity, adequate social income, identical religious beliefs, similar political beliefs, children, understanding and love. For other conditions, there is no statistical significance observed in terms of religious self-identification of students. In the subsample Bulgaria, it was found that students' religiosity determines only the views that fidelity, love, and children are prerequisites of a successful marriage. 
beliefs. By testing the statistical significance of these connections, we conclude that all the examined attitudes about the importance of individual factors for a successful marriage are to a greater or lesser extent determined by religious beliefs, specifically by expressed tolerance towards the truths offered by other religions. On the statistical significance and the extent of this dependence see the table below, which presents the results of testing the significance of all examined attitudes.

\begin{tabular}{|c|c|c|c|c|c|}
\hline & $\mathrm{X}^{2}$ & $\mathrm{DF}$ & $\mathrm{N}$ & SIG. & $\begin{array}{c}\text { CRAMER'S } \\
\mathrm{V}\end{array}$ \\
\hline FIDELITY & 71.127 & 12 & 2181 & 0,000 & 0,181 \\
\hline ADEQUATE INCOME & 81.263 & 12 & 2182 & 0,000 & 0,111 \\
\hline THE SAME SOCIAL BACKGROUND & 75.899 & 12 & 2177 & 0,000 & 0,108 \\
\hline SHARING THE SAME RELIGIOUS BELIEFS & 243.465 & 12 & 2177 & 0,000 & 0,193 \\
\hline GOOD HOUSING CONDITIONS & 41.543 & 12 & 2179 & 0,000 & 0,080 \\
\hline SimilaR POLITICAL BELIEFS & 58.509 & 12 & 2180 & 0,000 & 0,095 \\
\hline LIFE SEPARATED FROM PARENTS & 43.803 & 12 & 2177 & 0,000 & 0,082 \\
\hline GOOD SEXUAL RELATIONS & 56.991 & 12 & 2178 & 0,000 & 0,093 \\
\hline EQUAL PARTICIPATION OF SPOUSES IN HOUSEWORK & 52.868 & 12 & 2173 & 0,000 & 0,090 \\
\hline CHILDREN & 90.472 & 12 & 2178 & 0,000 & 0,118 \\
\hline MUTUAL UNDERSTANDING & 49.723 & 12 & 2179 & 0,000 & 0,087 \\
\hline $\begin{array}{l}\text { HAVING TIME FOR FRIENDS AND PERSONAL } \\
\text { ACTIVITIES AND HOBBIES }\end{array}$ & 51.046 & 12 & 2179 & 0,000 & 0,088 \\
\hline LOVE & 45.806 & 12 & 2180 & 0,000 & 0,084 \\
\hline
\end{tabular}

TABLE 2: AN OVERVIEW OF PARAMETERS SHOWING THE STATISTICAL SIGNIFICANCE OF DIFFERENCES IN STUDENTS' ATTITUDES TOWARDS CERTAIN FACTORS FOR A SUCCESSFUL MARRIAGE OBSERVED WITH REGARDS TO RELIGIOUS TOLERANCE

Even in this case we do not have a complete matching of established regularities at the level of the sample as a whole and in each subgroup since it was shown that in each of them different attitudes (than those listed in the instrument) appear to be determined by students' religious tolerance. Thus, with the students from Serbia, a statistical significance was not observed in the attitudes relating to the acceptance of the claim regarding similar political beliefs, good housing conditions, living away from parents, mutual 
understanding and love. With the students from Macedonia, there was no statistical significance in the attitudes about the importance of separation from parents, good sexual relations and the equal division of labor in the home between men and women, while the differences regarding all other factors of a successful marriage were statistically significant in the groups of subjects formed according to religious beliefs. However, in the subsample Bulgaria, of the thirteen factors that could affect the success of a marriage among students with varying degrees of religious tolerance, the statistical significance of the difference in the answers was determined only in four preconditions. Attitudes toward truths offered by different religions were associated in a statistically significant manner with the students' opinion on the importance of identical religious beliefs of spouses, their identical social origin, good housing conditions and having children as a precondition for a successful marriage.

Bearing in mind the findings at the level of the sample as a whole, but also on the basis of the differences in subsamples, we can conclude that despite the existence of a supposed base value orientation (which is located on a continuum between two points traditionalism - modernism), which determines the attitudes towards marriage and religious self-identification and religious tolerance making them closely linked, it is obvious that the results of testing the statistical significance of these connections suggest that it is reasonable to test the supposed relations with the inclusion of a number of parameters pertaining to religiosity, which would provide the possibility to classify the investigated population on a scale of strength and quality of religious beliefs. ${ }^{10}$

10 This statement finds a foothold in a number of tests on religiosity in which researchers insist that religious self-declaration is only one of the indicators of the population's religiosity, since recording religiosity must include the segment of religious participation and knowledge of the religious dogma (Pavićević, 1980; Blagojević, 2009a, 9-36; Blagojević, 2009b, 97-117; Sekulić, Šporer 2006, 1-19; Петровић, Шуваковић, 2013, pp. 245-263). 


\section{THE IMPORTANCE OF FAMILY AND ATTITUDES TOWARDS PLANNING FAMILY LIFE}

A number of previous studies on the importance that respondents attach to the family (Zaharijevski, 2005; Golubović, Spasić, Pavićević, 2003; Stjepanović-Zaharijevski, Petrović, 2009; Milić, 2010; Petrović, Suvaković, 2012; Gavrilović, 2013) show that the place of family is very highly positioned in the lives of a significant number of people in relation to other areas of life. There is no exception when it comes to the tested student youth. In assessing the importance of different areas of life, students from all studied countries, according to the average scores obtained from the evaluation of all the listed areas, perceived family as the most important sphere of life. Education, work and friendship are also areas of life that are very important to them, but the order that they occupy is different among students from different subsamples. To the students from the University of Niš and Veliko Tarnovo, after the family, the most important thing is education, while the Bitola University students favor work. To students in all three countries, the least the important areas are religion and politics.

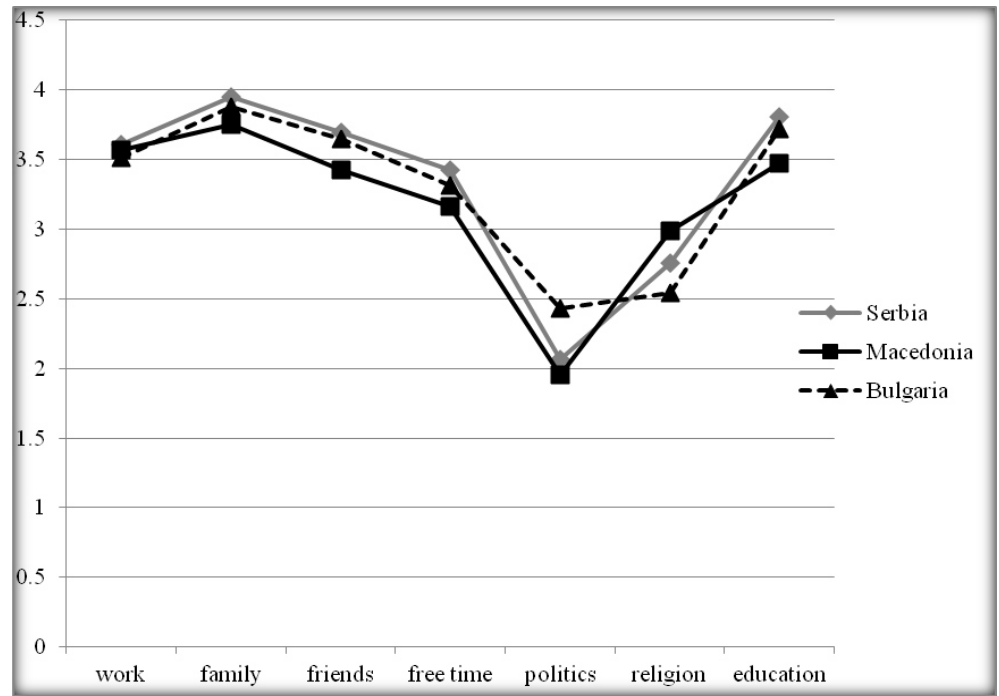

CHART 2. THE IMPORTANCE OF CERTAIN AREAS OF LIFE TO STUDENTS OF THE UNIVERSITY OF NIŠ, Bitola AND VELIKO TARNOVO (MEAN SCORES) 
From the distribution of frequencies of (dis)agreement with the positions representing the traditional/modern/postmodern value orientations when it comes to understanding family life and gender roles, we can conclude that among the students of all universities there is a persistence of different values (traditional, modern, postmodern). Certainly, a decade-long transformation of society in the Balkans must be followed by a value transformation and a parallel functioning of different value models in terms of family life (when it comes to Serbia, see more in Gavrilović, Zaharijevski, 2012; Milić, 2001; Blagojević, 2003; Захаријевски, Петровић, 2010, Ivanov, 2009; Petrović, 2014).

Observed from the level of the entire sample, the findings of this study are a kind of an indicator of value ambivalence of the student population. For example, students prefer a complete family (with both parents) as a model of family life (71.7\%), which is a traditional form, but also somewhat respect the decision of women who want to give birth and raise children outside of marriage (45.2\%), which is a modernist tendency and a shift towards individualization. Modernist beliefs are recognized in the results that the majority of students believe that the decision whether to become parents is the one they should make themselves (85.8\%). But at the same time, almost every fifth student considers biological reproduction to be a part of the obligations they have towards society (20.5\%), which is a recognizable marker of a traditional model of reproduction ("birth as a national interest"). It is necessary to point out the fact that in recent decades, at least when it comes to Serbia, the stance on women's duty to reproduce the nation is frequently publicly promoted, which is evident not only through public statements of the Serbian Orthodox Church, but also through well-designed media content (Minić, 2004, p. 50). Therefore, we consider claims that the change in the values in the countries in transition is reflected in the gender regimes to be well-founded (Blagojević, 2003; Zaharjevski, Petrović, 2014).

When it comes to the division of gender roles, on a declarative level stating that men should be equally responsible for the house and children as women, students expressed the desirability of equal division of family responsibilities (83.6\%), however, when this approach is concretized in the form of a request that the priority of working women is still the care of family members, the situation is changing. The share of examined population who agree with this statement, or is undecided, reaches almost two-thirds 
(63.6\%), which indicates the presence of stereotypical attitudes regarding gender roles, and that the traditional form of the family model expressed through readiness to live in a family where the woman mostly cares for the household and the offspring is still very widespread.

\begin{tabular}{|c|ccc|}
\hline CLAIMS & AGREE & UNDECIDED & DiSAGREE \\
\hline HAVING CHILDREN IS ONE'S DUTY TO SOCIETY & 27,5 & 15,7 & 56,8 \\
THE PEOPLE THEMSELVES MUST DECIDE WHETHER TO HAVE CHILDREN OR & 85,8 & 10,1 & 4,1 \\
NOT & & & \\
IT'S ALL RIGHT THAT WOMEN GIVE BIRTH AND RAISE CHILDREN OUT OF & 45,2 & 28,6 & 26,3 \\
MARRIAGE. & & & \\
A HOME WITH BOTH PARENTS IS NECESSARY FOR A HAPPY CHILDHOOD. & 71,7 & 15,8 & 12,5 \\
EMPLOYMENT IS ALL RIGHT, BUT IT IS A WOMAN'S PRIORITY TO TAKE CARE & 36,2 & 27,4 & 36,4 \\
OF THE HOUSEHOLD & & & \\
MEN SHOULD BE EQUALLY RESPONSIBLE FOR THE HOUSE AND CHILDREN AS & 83,6 & 10,8 & 5,6 \\
WOMEN & & & \\
\hline
\end{tabular}

TABLE 3: THE DISTRIBUTION OF ANSWERS TO GIVEN CLAIMS (FINDINGS ON THE SAMPLE AS A WHOLE EXPRESSED IN \%)

While the average value of the scores indicates that there is an identical attitude in students from all three countries - that the family as an existential field and the most important area of life, they are not unique (at a level of subsamples) when it comes to the way in which family life should be regulated, or even in relation to the social importance of some of its functions. Thus, students from the Macedonian sub-sample more frequently express the view that having children is one's duty to society than their counterparts from Bulgaria and Serbia do. At the same time, they more rarely accept the possibility that women give birth and raise children outside of marriage and rarely accept the notion that men should be equally responsible for the house and children as women (Table 4). Serbian students are more flexible than their counterparts from other countries when it comes to extramarital procreation and raising children and simultaneously in the fewest number of cases accept the notion that women's priority is taking care of the house and children regardless of employment.

When we compare the differences in the attitudes of students on regulating family relations as seen through their religious self- 
Students' Perception Of Marriage, FAmily AND PARenthood...

\begin{tabular}{|c|c|c|c|c|c|c|c|c|c|}
\hline \multirow{2}{*}{$\begin{array}{c}\text { CLAIMS ABOUT } \\
\text { FAMILY, } \\
\text { PARENTHOOD AND } \\
\text { GENDER RELATIONS }\end{array}$} & \multicolumn{3}{|c|}{ AGREE } & \multicolumn{3}{|c|}{ UNDECIDED } & \multicolumn{3}{|c|}{ DISAGREE } \\
\hline & Srb & $\mathrm{Mk}$ & Bug & Srb & Mk & Bug & Srb & $\mathrm{Mk}$ & Bug \\
\hline $\begin{array}{l}\text { HAVING CHILDREN } \\
\text { IS ONE'S DUTY TO } \\
\text { SOCIETY }\end{array}$ & 20,5 & 35,0 & 26,8 & 12,4 & 20,5 & 13,8 & 67,1 & 44,5 & 59,4 \\
\hline $\begin{array}{c}\text { THE PEOPLE } \\
\text { THEMSELVES MUST } \\
\text { DECIDE WHETHER TO } \\
\text { HAVE CHILDREN OR } \\
\text { NOT }\end{array}$ & 89,5 & 78,9 & 90,5 & 7,7 & 14,3 & 7,4 & 2,8 & 6,8 & 2,1 \\
\hline $\begin{array}{c}\text { IT'S ALL RIGHT } \\
\text { THAT WOMEN GIVE } \\
\text { BIRTH AND RAISE } \\
\text { CHILDREN OUT OF } \\
\text { MARRIAGE }\end{array}$ & 62,5 & 35,3 & 33,9 & 21,0 & 35,0 & 30,5 & 16,5 & 29,7 & 35,6 \\
\hline $\begin{array}{c}\text { A HOME WITH BOTH } \\
\text { PARENTS IS } \\
\text { NECESSARY FOR A } \\
\text { HAPPY CHILDHOOD }\end{array}$ & 63,4 & 71,0 & 84,5 & 18,7 & 18,4 & 8,1 & 17,9 & 10,6 & 7,4 \\
\hline $\begin{array}{c}\text { EMPLOYMENT IS } \\
\text { ALL RIGHT, BUT IT IS } \\
\text { A WOMAN'S } \\
\text { PRIORITY TO TAKE } \\
\text { CARE OF THE } \\
\text { HOUSEHOLD }\end{array}$ & 28,6 & 38,4 & 44,1 & 29,3 & 31,2 & 19,4 & 42,1 & 30,3 & 36,5 \\
\hline $\begin{array}{l}\text { MEN SHOULD BE } \\
\text { EQUALLY } \\
\text { RESPONSIBLE FOR } \\
\text { THE HOUSE AND } \\
\text { CHILDREN AS } \\
\text { WOMEN }\end{array}$ & 88,1 & 73,2 & 91,5 & 8,2 & 16,2 & 6,9 & 3,7 & 10,6 & 1,6 \\
\hline
\end{tabular}

TABLE 4: THE DISTRIBUTION OF ANSWERS TO GIVEN CLAIMS (FINDINGS ON SUBSAMPLES EXPRESSED IN \%)

determination, we see that a statistical significance occurs in all investigated attitudes.

Observing the share of specific groups created based on religious declaration in groups of students who agree with the offered positions we see that "firm" believers (those who accept everything 


\begin{tabular}{|c|cccccc|}
\cline { 2 - 6 } \multicolumn{1}{c|}{} & $\mathrm{X}^{2}$ & DF & $\mathrm{N}$ & Sig. & $\begin{array}{c}\text { CRAMER'S } \\
\text { V }\end{array}$ \\
\hline $\begin{array}{c}\text { THE PEOPLE THEMSELVES MUST DECIDE WHETHER CHILDREN IS ONE'S DUTY TO SOCIETY } \\
\text { TO HAVE CHILDREN OR NOT }\end{array}$ & 45.085 & 10 & 2159 & 0,000 & 0,102 \\
$\begin{array}{c}\text { IT'S ALL RIGHT THAT WOMEN GIVE BIRTH AND RAISE } \\
\text { CHILDREN OUT OF MARRIAGE }\end{array}$ & 32.232 & 10 & 2159 & 0,000 & 0,086 \\
$\begin{array}{c}\text { A HOME WITH BOTH PARENTS IS NECESSARY FOR A } \\
\text { HAPPY CHILDHOOD }\end{array}$ & 53.958 & 10 & 2160 & 0,000 & 0,112 \\
$\begin{array}{c}\text { EMPLOYMENT IS ALL RIGHT, BUT IT IS A WOMAN'S } \\
\text { PRIORITY TO TAKE CARE OF THE HOUSEHOLD }\end{array}$ & 65.778 & 10 & 2158 & 0,000 & 0,123 \\
$\begin{array}{c}\text { MEN SHOULD BE EQUALLY RESPONSIBLE FOR THE } \\
\text { HOUSE AND CHILDREN AS WOMEN }\end{array}$ & 36.401 & 10 & 2152 & 0,000 & 0,092 \\
\hline
\end{tabular}

TABLE 5: OVERVIEW OF PARAMETERS SHOWING THE STATISTICAL SIGNIFICANCE OF DIFFERENCES IN STUDENTS' ATTITUDES TOWARDS FAMILY LIFE AND GENDER ROLES OBSERVED THROUGH THEIR RELIGIOUS SELF-DECLARATION

their religion teaches) more often than moderate believers or those who are not confident in their religious beliefs, or are indifferent to faith, manifest traditional attitudes. For example, firm believers more often than others believe that having children is a duty to society, which is not surprising if one takes into account the present dominant demographic discourse in recent decades, which is inseparably associated with religious discourse, both of which are focused on trying to instrumentalize population's reproductive policy (see Blagojević 2003, p. 168). Also, firm believers more often agree with the view that children should grow up in a home with both parents, as well as that it is a priority of women to nurture and care for the children and the household. The same group of respondents, less often than other categories of subjects formed according to religious self-identification, considers that men share the same responsibility for the home and children as women, and that it is acceptable for women to give birth and raise children out of marriage. It is interesting that apart from firm believers, in terms of traditional attitudes towards family life and gender roles, a prominent place belongs to those students who identified themselves as opponents to religion (Table 6).

When comparing the differences in the attitudes of students towards the regulation of family relations and in the domain of 
Students' Perception Of MARriage, FAmily ANd PARENTHOOD...

\begin{tabular}{|c|c|c|c|c|c|c|}
\hline & $\begin{array}{c}\text { FIRM } \\
\text { BELIEVERS }\end{array}$ & $\begin{array}{c}\text { MODERATE } \\
\text { BELIEVERS }\end{array}$ & $\begin{array}{l}\text { UNSURE OF } \\
\text { THEIR } \\
\text { RELIGIOUS } \\
\text { STATUS }\end{array}$ & $\begin{array}{l}\text { INDIFFERENT } \\
\text { TO RELIGION }\end{array}$ & $\begin{array}{c}\text { NoN } \\
\text { RELIGIOUS }\end{array}$ & $\begin{array}{l}\text { OPPOSED } \\
\text { TO } \\
\text { RELIGION }\end{array}$ \\
\hline $\begin{array}{l}\text { HAVING CHILDREN } \\
\text { IS ONE'S DUTY TO } \\
\text { SOCIETY }\end{array}$ & 33,8 & 23,6 & 27,5 & 23,2 & 21,4 & 33,9 \\
\hline $\begin{array}{c}\text { THE PEOPLE } \\
\text { THEMSELVES MUST } \\
\text { DECIDE WHETHER TO } \\
\text { HAVE CHILDREN OR } \\
\text { NOT }\end{array}$ & 82,9 & 89,2 & 84,6 & 86,1 & 88,2 & 72,9 \\
\hline $\begin{array}{l}\text { IT'S ALL RIGHT THAT } \\
\text { WOMEN GIVE BIRTH } \\
\text { AND RAISE } \\
\text { CHILDREN OUT OF } \\
\text { MARRIAGE }\end{array}$ & 38,3 & 45,9 & 49,0 & 47,7 & 53,9 & 39,0 \\
\hline $\begin{array}{c}\text { A HOME WITH BOTH } \\
\text { PARENTS IS } \\
\text { NECESSARY FOR A } \\
\text { HAPPY CHILDHOOD }\end{array}$ & 80,4 & 71,9 & 66,4 & 70,2 & 59,9 & 66,1 \\
\hline $\begin{array}{c}\text { EMPLOYMENT IS ALL } \\
\text { RIGHT, BUT IT IS A } \\
\text { WOMAN'S PRIORITY } \\
\text { TO TAKE CARE OF } \\
\text { THE HOUSEHOLD }\end{array}$ & 44,5 & 34,4 & 28,5 & 41,1 & 27,7 & 37,3 \\
\hline $\begin{array}{c}\text { MEN SHOULD BE } \\
\text { EQUALLY } \\
\text { RESPONSIBLE FOR } \\
\text { THE HOUSE AND } \\
\text { CHILDREN AS } \\
\text { WOMEN }\end{array}$ & 80,5 & 88,8 & 84,2 & 82,0 & 81,9 & 69,0 \\
\hline
\end{tabular}

TABLE 6: THE PERCENTAGE OF AGREEMENT WITH THE STUdENTS' ATTITUDES (ABOUT FAMILY LIFE AND GENDER ROLES) OBSERVED THROUGH RELIGIOUS SELF-DETERMINATION (FINDINGS IN \%)

gender roles observed according to the established religious tolerance, we see that a statistical significance occurs in all investigated attitudes, and that the connection between religious beliefs and these attitudes is even more pronounced than in the case of differences observed through religious self-declaration (Table 7). This 
difference is particularly compelling in the understanding of gender roles in the family and in relation to parenting as a "debt" to society.

\begin{tabular}{|c|cccccc|}
\cline { 2 - 6 } \multicolumn{1}{c|}{} & X & DF & N & Sig. & $\begin{array}{c}\text { CRAMER'S } \\
\text { V }\end{array}$ \\
\hline $\begin{array}{c}\text { THE PEOPLE THEMSELVES MUST DECIDE WHETHER CHILDREN IS A DUTY TO SOCIETY } \\
\text { TO HAVE CHILDREN OR NOT }\end{array}$ & 61.015 & 8 & 2179 & 0,000 & 0,118 \\
$\begin{array}{c}\text { IT'S ALL RIGHT THAT A WOMAN GIVES BIRTH AND } \\
\text { RAISE A CHILD OUT OF MARRIAGE }\end{array}$ & 30.489 & 8 & 2181 & 0,000 & 0,084 \\
$\begin{array}{c}\text { A HOME WITH BOTH PARENTS IS NECESSARY FOR A } \\
\text { HAPPY CHILDHOOD }\end{array}$ & 69.256 & 8 & 2180 & 0,000 & 0,126 \\
$\begin{array}{c}\text { EMPLOYMENT IS ALL RIGHT, BUT IT IS A WOMAN'S } \\
\text { PRIORITY TO TAKE CARE OF THE HOUSEHOLD }\end{array}$ & 74.951 & 8 & 2178 & 0,000 & 0,131 \\
$\begin{array}{c}\text { MEN SHOULD BE EQUALLY RESPONSIBLE FOR THE } \\
\text { HOUSE AND CHILDREN AS WOMEN }\end{array}$ & 38.037 & 8 & 2171 & 0,000 & 0,094 \\
\hline
\end{tabular}

TABLE 7: AN OVERVIEW OF PARAMETERS SHOWING THE STATISTICAL SIGNIFICANCE OF DIFFERENCES IN STUDENTS' ATTITUDES TOWARDS FAMILY LIFE AND GENDER ROLES OBSERVED THROUGH THE ESTABLISHED RELIGIOUS TOLERANCE

TOWARDS CONCLUSION
The student population at three university centers in the Balkans is making steps towards modern value orientations. In their value systems, there is a persistent mixture of traditional forms and modernist tendencies with a clear shift toward individualization which involves reshaping intimate relationships in a more egalitarian and vital form ("individualistic model of partnership"), but also redefining gender roles and "symmetrical parenting". It is not possible to talk about structured value models, particularly because the sphere of partner and family relationships, reproduction and gender regime are seen as very important and sensitive spheres of existence and the processes of "long duration", so it is not expected that the social, economic and cultural development necessarily follow the expected transformation in these areas of life, especially because of the findings that the investigated student population is not completely homogenous in their own perception of the content and that there is a significant proportion of those sympathetic to 
traditional value matrices, stereotypes and prejudices, which again reproduce discriminatory patriarchal patterns, despite the fact that we are talking about young and educated people. By introducing religiosity into the analysis, as an inevitable marker of traditionalism, the picture is clearer: students' religious selfidentification and the rigor of their religious beliefs predicate the attitudes towards marriage, family and parenthood: students who declare themselves as firm believers and those who show a lower level of religious tolerance to other religions have more traditional beliefs.

Students' attitudes towards the assumptions of a successful marriage, towards family and parenting suggest a removal from material connections and a choice of affective-psychological patterns and a "romantic complex" (Milić, 2001, p. 124). Almost without exception, regardless of the country they are from, students feel that for a successful marriage mutual understanding, fidelity and love are of special importance. But preconditions recognized further can point to the conclusion that, for example, with Macedonian students the conditions that indicate traditional establishment (income, job, shared beliefs) take precedence, while with Bulgarian and Serbian students there is a departure from traditional assumptions as they mark good sexual relations, independence and time to meet their own needs. All examined attitudes about the importance of individual factors for a successful marriage are to a greater or lesser extent determined by religious beliefs.

Without exception, to all students, family is the most essential sphere of life, followed by the education, work and friendship. The least important areas are religion and politics. The importance of the family and attitudes towards the regulation of family life at a first glance may support the findings on the traditional value discourse. Assigning a key significance to the family needs further investigation, particularly because of the fact that the family appears as the most important sphere of life in the findings of the global and European studies on values performed in societies which are by many parameters developed and modern. Also, a characteristic of the studied value context is the expressed ambivalence in the students' choice of the offered attitudes, indicating value turmoil. Nevertheless, the dominant choices and preferences clearly point to a clear orientation towards the individual and egalitari- 
an values and a shift in the perception of partnership as a "vital and pure relationship" (Giddens, 1992).

The regulation of the family life, partnership and gender roles according to the distribution of chosen attitudes that represent traditional, modern and postmodern value orientations exudes their simultaneous persistence, although it is completely clear that the decade-long social transformation of Balkan countries is followed by a transformation of values. When comparing the differences in the students' attitudes towards the regulation of family relations in the domain of gender roles observed through religious tolerance, we see that a statistical significance occurs in all investigated attitudes, and that the connection between religious beliefs and these attitudes is even more pronounced than in the case of differences observed by religious self-declaration. This difference is particularly compelling in the understanding of gender roles in the family and in relation to parenting as a "debt" to society.

Presented findings indicate the need for adjusting the assessment given by eminent researchers a decade ago which considers young people as "lost in transition". Our research sees the student population in the Balkans as actors in the transition from traditional values to modern and postmodern ones, given their prevailing rational choices and a more pronounced individuality.

Blagojević, M. (2003). „Promena vrednosti i rodni režim u zemljama u 'tranziciji': komparativna perspektiva". U Lj. Baćević i dr. (prir.), Promene vrednosti i tranzicija u Srbiji: pogled u budućnost. Beograd: Fridrich Ebert Stifung, IDN.

Blagojević, M. (2009b). „Revitalizacija religije i religioznosti u Srbiji: stvarnost ili mit”. Filozofija i društvo, 38 (2), 97-117.

Blagojević, M. (2009a). „O sociološkim kriterijumima religioznosti: Koliko ima (pravoslavnih) vernika danas?" Filozofija i društvo, 37 (1), 9-36.

Gavrilovic, D. (2013). Doba upotrebe: Religija i moral u savremenoj Srbiji. Niš: Filozofski fakultet.

Giddens, A. (1992). The Transformation of Intimacy (Sexuality, Love \& Eroticism in Modern Societies). Stanford: Stanford University Press.

Golubović Z., I. Spasić, Pavićević Đ. (ur.) (2003). Politika i svakodnevni život - Srbija 1999-2002. Beograd: Institut za filozofiju i društvenu teoriju.

Inglehart, R., Wayne, E. B. (2000) Modernization, Cultural Change, and the Persistence of Tradicional Values. American Sociological Review, 65 (1), 19-51. 
Inglehart, R. Welzel, C. (2010) Changing Mass Priorities: The Link between Modernization and Democracy. Perspectives on politics, (2), 551-567.

Ivanov, J. (2009). Profil rodnih odnosa na Kosovu i Metohiji: između "poželjnog" i stvarnog. Godišnjak za sociologiju 5(5), 155-169.

Milić, A. (2001). Sociologija porodice. Beograd: Čigoja štampa.

Milić, A. i dr. (2010) Vreme porodica. Sociološka studija o porodičnoj transformaciji u savremenoj Srbiji. Beograd: ISI FF, Čigoja štampa.

Minić, D. (2004). „Nacija i pol u patriotskom spotu BK televizije”. Genero - posebno izdanje: Žene i mediji, 49-57.

Pavićević, V. (1980). Sociologija religije sa elementima filozofije religije. Beograd: Beogradski izdavačko-grafički zavod.

Petrovic J., Suvakovic U. (2012). Social Goals and Values of Belgrade University Students. Весйник РУДН, серия Социолоїия, 1, 90-102.

Petrović, J. (2014). Između tradicionalnog nasleđa i težnje ka modernim obrascima života: brak, porodica i porodični odnosi Roma u Srbiji. U V. Sokolovska (prir.), Društveni i kulturni potencijali Roma u Srbiji (str. 29-53). Novi Sad: Filozofski fakultet.

Петровић, J. (2014). „Основне информације о узорку, инструменту и теренској реализацији емпиријског истраживања 'Културна оријентација актера/студената, међуетнички односи, национални идентитет и култура мира на Балкану”. У Д. Захаријевски, Г. Ђорић, Г. Стојић

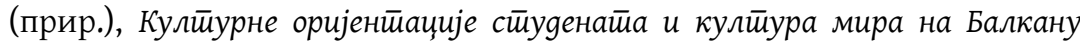
(стр. 11-16). Ниш: Филозофски факултет.

Петровић, Ј., Шуваковић, У. (2013). Религиозност, конфесионална дистанца и место верске припадности у структури идентитета студената Универзитета у Косовској Митровици. У 3. Милошевић, Ж. Бурић

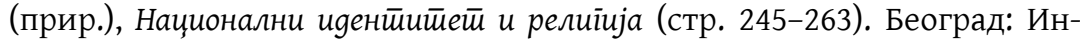
ститут за политичке студије.

Sekulić, D., Šporer, Ž. (2006). „Religioznost kao prediktor vrijednosnih orijentacija". Revija za sociologiju, 37 (1-2), 1-19.

Zaharijevski, D. (2005) Sociologija porodice kao društvena nauka i porodična stvarnost. Niš: MB grafika.

Zaharijevski D., Gavrilović, D. (2010). „Identiteti i porodične vrednosne orijentacije na Balkanu”. Sociologija 52 (1), 23-40.

Zaharijevski, D. i Petrović, J. (2009). „Porodične vrednosne matrice u zavisnosti od konfesionalne i nacionalne pripadnosti". U Ljubiša Mitrović, Dragana Stjepanović-Zaharijevski i Danijela Gavrilović (prir.), Međuetnički odnosi identiteti i kultura mira na Balkanu, (str. 73-90). Niš: Centar za sociološka istraživanja Filozofskor fakulteta Univerziteta u Nišu. 
Zaharijevski, D., Petrović, J. (2010). „Rodna ravnopravnost i održivi razvoj”. U Uroš Šuvaković (ur.), Kosovo i Metohija u civilizacijskim tokovima, knj. 4. (str. 357-378). Kosovska Mitrovica: Filozofski fakultet Univerziteta u Prištini.

Zaharijevski, D., Petrović J. (2014). „Percepcija braka, porodice i roditeljstva studentske omladine u svetlu drmografskih i socijalnih determinanti". U D. Zaharijevski, G. Đorić, G. Stojić (ur.), Kulturne orijentacije studenata i kultura mira na Balkanu (str. 217-231). Niš: Centar za sociološka istraživanja Filozofskog fakulteta u Nišu. 
ЈАСМИНА С. ПЕТРОВИК

ДРАГАНА С. ЗАХАРИЈЕВСКИ

УНИВЕРЗИТЕТ У НИШУ

ФИЛОЗОФСКИ ФАКУЛТЕТ

РЕЗИМЕ

\author{
ПЕРЦЕПЦИЈА БРАКА, ПОРОДИЦЕ И РОДИТЕЉСТВА СТУДЕНТСКЕ \\ ОМЛАДИНЕ У СВЕТЛУ РЕЛИГИЈСКЕ ИДЕНТИФИКАЦИЈЕ И ВЕРСКЕ \\ ТОЛЕРАНЦИЈЕ: КОМПАРАТИВНА ПЕРСПЕКТИВА
}

На подацима добијеним у оквиру истраживања Кулӣурна

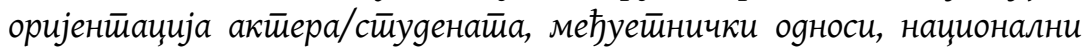

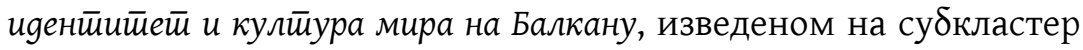
узорку студената универзитета у Нишу, Битољу и Великом Трнову, у компаративној перспективи тести-ра-на је општа претпоставка о истовременом присуству традиционалних и модерних ставова у поимању брака, породице, родитељства и родних односа. Такође, претпостављено је да постоји разлика у испољеним ставовима у поменутим областима међу студентима који се различито одређују према религији: убеђени верници и они који исказују мањи степен толеранције на верска учења чешће имају традиционална уверења о браку, породици и родним односима. Хипотезе су провераване кроз тестирање статистичких разлика у одговорима испитаника у групама формираним према религијској самоидентификацији и утврђеним ставовима о верским садржајима и сагледани у упоредној перспективи у три државе.

На нивоу општих налаза истраживања констатовано је да није могуће говорити о структурисаним вредносним моделима када је у питању однос студената према браку, породици, породичним и родним односима. Разлог томе треба тражити у чињеници да сфера партнерских и породичних веза, репродукција и родни режим спадају у веома значајне и осетљиве сфере бивствовања и процесе „дугог трајања”, тако да није за очекивати да друштвени, економски и културни развој нужно прати очекивана трансформација у овим областима живота. Стога и испитивана студентска популација није у потпуности хомогена у властитој перцепцији поменутих садржаја, при чему је значајан удео оних наклоњених традиционалним вредносним матрицама, стереотипима и предрасудама, које изнова репродукују патријархалне дискриминативне обрасце, упркос чињеници да је реч о младим и образованим људима. Увођењем у анализу религиозности, као незаобилазног маркера традиционалности тестирана је претпо- 
ставка о томе да религијска уверења студената „боје” њихов однос према испитиваним ставовима. Потврђено је да су религијска самоидентификација студената и чврстина њихових верских уверења предикатори ставова према браку, породици и родитељству: студенти који се изјашњавају као убеђени верници, као и они који исказују нижи степен верске толерантности према другим верама имају традиционалнија уверења.

КљУчнЕ РЕчи: ठрак, породица, родитељство, Битољ, Велико Трново, Ниш, студенти. 